\title{
Exploration on Effects of Parents' Participation in College Management under New Normal
}

\author{
Shuting Tian \\ Mianyang Teachers' College \\ Mianyang, China 621000
}

\begin{abstract}
Higher education trains professional and intelligent talents for the society, concerning the national economic development and social modernization process. People with interests related to higher education under participate in college management under new normal. Parents of students who benefit from higher education should take the initiative to participate in the college management and construction and make contributions to train excellent talents for the socialist construction cause.
\end{abstract}

Keywords - higher education; new normal; family education

\section{INTRODUCTION}

"Higher education under new normal transforms from single and unidirectional management pattern to diversified modern management pattern with shared governance. People with interests related to higher education participate in the governance through reasonable system design and procedural arrangements." [1] Parents should take the initiative to participate. Soviet educator Sukhomlinskii once said, "Educational effects depend on the consistency of educational influences from school and family. Without it, school teaching will collapse like the house made of paper". Parents' participation in educational management in colleges makes school work more pertinent and effective and promotes students' growth.

\section{NECESSITY OF PARENTS' PARTICIPATION IN EDUCATIONAL MANAGEMENT}

In the period of social transformation, with the "decentralization" of the authority of school education, the improvement of parents' cultural quality and the popularization of the thought of life-long education, family education will play a more important role.

First, family is the natural school for children to receive education. Parents provide material needs and spiritual nourishment for children and make them feel safe and happy. Family education is the basis for individuals to continue to receive education. It resembles a filter to filtrate and purify the education and influence on individuals outside the family and strengthen or weaken outside influence [2], to make individuals form traits of character, volitional quality and behavior habits. Harmonious relationship between parent and child and the healthy and scientific educational concept are the strong backing for children to keep their mind on studying and realize smooth socialization. At present, the psychological health problems of college students have become a distinctly important part of educational management. Psychological problems are inseparable from the life experience and family education of students. The adjustment and recuperation of it cannot do without the support of family members. Obviously, the non-intelligence education on children from the family cannot be replaced by society and school.

Second, as the investor for children to receive higher education, parents have right to supervise and regulate the development situation of children. The prospective earnings that parents invest to let children receive education are to transform human resource into human capital and improve the social status and income level of children, also including psychic income like psychic gratification and the glory of the family. Students' physical and psychological health, learning and life from admission to graduation directly or indirectly influence parents' investment income, make parents' prospective earnings have great uncertainty and delay. Once the children have accidents, parents may fail to recover cost or yield few results. In reality, some college students enjoy parents' selfless giving and financial support, compare unrealistically and have inflated material needs, and become profligate. They take campus loan with low threshold as the shortcut to satisfy their vanity. Some students are trapped in it, using extreme behaviors to facing the press for payment of debt or making the family debt-ridden. These behaviors of college students impede their growth and seriously influence parents and family life. Therefore, parents have right and cannot voluntarily give up the right to supervise students' situation in school.

Third, it stipulates in the No. 24 Provisions on the Construction of College Counselors Team of the order of the Ministry of Education of the People's Republic of China, "Colleges shall make the teacher-student ratio no less than one to two hundred to set undergraduate and junior college student and the front line full-time counselor post." College Counselors' Professional Competence Standard (Temporary) stipulates counselors' vocational ability and job contents. It shows counselors have detailed and complicated daily work and involve broad scope of vocational ability, so it is impossible for them to roundly know about the specific circumstance of each student. Moreover, college years are key period for students to establish outlook on life and values. They need to face ideological, psychological, emotional 
problems, learning and life pressure, deal with interpersonal relationships. It will have serious consequences with misconduct or without effective guidance and help. Parents pay attention to every word and action of children and have an insight into their emotional changes. Once the above problems appear, parents can timely provide the newest and the most important information for counselors so that the problems will be controlled in the bud.

Fourth, the economic development in our country enters the new normal. The development of higher education must adapt to new changes and center on quality improvement. The reform and education of higher education proposes new requirements for family education on how to coordinate with school education. Parents should update educational concept, educate children with science instead of experience and establish the concept of life-long learning. Meanwhile, carry out unceasing transcendental ego, mutual learning and influence with children, in order to improve the effectiveness of family education. Educator Sukhomlinskii said, "Without education from the society especially the family, no matter how hard the teachers try, no perfect effects will be achieved. All problems in school will reflect in family. The difficulty of complicated education in school can trace back to family". Good family education is the powerful supplement of school education. Parents have right and obligation to participate in the management and coordinate with the school in education.

\section{CURRENT SituAtion OF PARENTS' PARTICIPATION IN EDUCATIONAL MANAGEMENT}

With the popularization of school education and the continuous improvement of proportion and level of receiving education in society, parents' cultural quality greatly improves. Some parents with high quality begin to evaluate and participate in school education. Objectively speaking, because of the different regions, languages, educational concepts and cultural levels, it is impossible to effectively realize the communication between parents and colleges. After entering colleges, most students stay away from parents and think they no longer need parents' care because they are mature and have ability in independent living and thinking. Some parents only provide economic support for children, lack the consciousness to participate in education of children, and totally depend on school and voluntarily give up the opportunity in education of children. Some parents even fail to contact the school until students graduate. The current situation of parents' participation in educational management of colleges includes:

First, few parents actively participate in education and their concerns are one-sided. At present, parents participate in the educational management through contacting college counselors by telephone to know about students' situation in school. Parents care more about students' intelligence factors like "How the child perform in the examination?" "What is the child's ranking in the examination?" Obviously, parents have no idea about the teaching mode of college, students' learning and life style and the training objectives of the school, and pay inadequate attention to non-intelligence factors like ideology and morality, social adaptive ability, physical and psychological health, aesthetic taste, life education and legal education.

Second, parents overprotect children. Nowadays, most college students are the only child in their family. Parents treasure them and are unwilling to let children bear hardships These students never leave home before entering colleges. They have simple interpersonal relationship, poor self-care ability and strongly depend on parents. They have strained relation with classmates because of living habits and deal with problems through cold war and emotional abuse, failing to communicate with classmates effectively. After students complain to parents, some parents maintain the vested interests of their children and neglect the source of contradictions. Parents tend to know about shortcuts beyond the policy in entering a higher school, appraising and joining the Party. They support when students ask for leave because of leaving school in advance and going back to school lingeringly. Parents often regard and evaluate problems through considering the growth of their children. The excessive concern and intervention of parents impedes the improvement of students' ability in independent thinking and problem solving and go against the training of students' consciousness of responsibility.

Third, parents' uneven ability in participating in the management leads to non-ideal educational effects. Because of the restriction of geographic position, degree of education and way of communication, parents have different ability to participate in student education. When counselors need parents to coordinate, some parents show helplessness and some are autocratic. The improper education makes the counselors' work more difficult. When students stay away from school and skip classes, have academic warning, stay out late and fail to come back, become drunken and fight with others and have emotional puzzle, some parents can coordinate with the school to help students successfully. Some parents are willing to participate in the education of students but bring little effect. Some fail to solve problems because of poor communication with children, and on the contrary, they make students opposed to counselors, making the educational management more difficult. Obviously, parents' participation in educational management produces very little effects. The ways and methods need improvement.

\section{EFFECTS OF PARENTS' PARTICIPATION IN EDUCATIONAL MANAGEMENT UNDER NORMALIZATION}

Modern colleges moving towards diversified management urgently need parents' participation in educational management and exert their irreplaceable educational advantages to realize the benign interaction of school education and family education. It is necessary to gradually improve the system of parents' participation in educational management in reform and innovation of colleges to provide solid guarantee for the substantial reform of higher education.

First, parents' participation in educational management contributes to the establishment of learning-oriented society. With the soaring development of science and technology, the aging period of knowledge in human society shortens and the 
knowledge update develops rapidly. People have to carry out lifelong learning for survival and development. According to the theory of lifelong development psychology, people's development is the process of dynamic change. The educational function and cultural inheritance pattern of family also develops correspondingly. Therefore, in today's society with cultural feedback phenomenon, parents that undertake the task of educating children must keep pace with the times, timely update knowledge and ideology and give proper advice for children as well as influence students' key choice. The improvement of learning idea in family promotes the prosperity and development of family education and improves the cultural and moral quality of citizens and their ability in survival and development.

Second, parents' participation in educational management makes for the realization of talent training objectives. College students have systematic scientific and cultural knowledge, thinking ability and independent personality. Bold changes happen in today's society. Unstable ideology and diversified values seriously influence students to establish correct world outlook, outlook on lie and values, making college education more difficult and restrict the realization of educational objectives. It is easier for parents to regulate behaviors of children because of the special intimacy of parents and the trust and attachment of students on parents. [3] Family education greatly influences college students. The educational effects will be consolidated and improved through stimulating parents' enthusiasm in participating in management and making them coordinate with the school to organize and implement teaching and skill training according to law of education and students' growth. School education has the advantages to provide guidance for family education and strengthens the cooperation to promote smooth socialization of college students.

Third, parents' participation in educational management makes for the benefit maximization of family investment. From the perspective of economics, college education carries out the reproduction of human resources. The country, society and family invest in education. The investment return is to train students into laborers that conform to training objectives, and they can use knowledge and skills to contribute to the society, family and other investors. Students' comprehensive quality, the changes of requirements of job market, restriction in transmission of employment information and utilitarian idea will influence the investment return of family in higher education. In order to maximize the investment interest, parents can participate in educational management, supervise and urge and train students' comprehensive ability, making employment preparation and timely dealing with risks that family investment may face.

\section{CONCLUSION}

It is the fine tradition of our country to value family education. Many countries recognize the legal status of family education and define the objectives and tasks of it. The country and social organizations should guide public opinion from system aspect, highlight the important position and role of family education in growth and healthy education of people and scientifically understand the values and advantages of parents in education activities for college students; colleges must make the best of educational resources and network platforms, guide parents to grasp methods and ways of family education and make the parents' participation in college education institutionalization and normalization, in order to cultivate high quality talents for socialist modernization.

\section{REFERENCES}

[1] Chen Xianzhe. Higher Education in Our Country Faces Dual Transformation under New Normal [DB/OL], China Social Science Network, http://www.qstheory.cn/freely/201503/11/c_1114602316.htm/, Mar.11, 2015

[2] Huang Heqing. Parents' Education [M], Shanghai: East China Normal University Press, 2014(5)

[3] Yang Yongqing. Discussion on the Effects of School Education and Family Education on the Growth of College Students [J], Shandong Institute of Commerce and Technology, 2006(6)

[4] Lin Guoliang. Problems of Parents' Participation in Student Management in Colleges and Countermeasures [J], Modern Education, 2010, (11)

[5] B.A.Sukhomlinskii, Suggestions for Teachers [M], Beijing: Educational Science Publishing House, 1984(6)

[6] Cheng Lu. Challenges Faced by College Students' Family Education and Point of Strength [J], Education and Vocation, 2008, (3)

[7] Zou Qiang. Research on Problems in Family-school Collaboration in Foreign Countries and Enlightenment [J], Journal of Teaching and Management, 2011, (4)

[8] Zeng Tao. Current Situation of College Student Management and Thinking [J], Journal of Changsha Railway University (Social Science), 2010, (11)

[9] Li Zhengjie. Problems of Non-intelligence Family Education of College Students Born after 1990 and Countermeasures [J], School Party Construction and Ideological Education, 2014, (12)

[10] Huang Wenjing. Family-school Education-New Thoughts on Effects of Family Education of College Students Born after 1990 [J], Higher Education Forum, 2013, (3) 